\title{
SEJARAH DAN PENGERTIAN BORLAND DELPHI 7
}

\author{
Muhammad Ridho Febrian Saputra \\ 185110013 \\ Fakultas Komputer \\ ridhofebrian.student@umitra.ac.id
}

\begin{abstract}
Abstrak
Delphi adalah sebuah bahasa pemrograman visual di lingkungan windows ( under windows) yang menggunakan bahasa pascal sebagai Compiler. Keberadaan bahasa pemrograman Delphi tidak bisa dipisahkan dari bahasa Turbo pascal yang diluncurkan pada tahun 1983 oleh Borland International Incorporation. Dengan menggunakan Free Pascal yangmerupakan proyek opensource, bahasa ini dapat pula digunakan untuk membuat programyang berjalan di sistem operasi Mac OS X dan Windows CE.Khusus untuk pemrogaman database, Borland Delphi menyediakan fasilitas obyek yangkuat dan lengkap yang memudahkan programmer membuat program untuk aplikasi database.Format database yang dimiliki Delphi yaitu format database Paradox, dBase, MS Access, ODBC, SyBASE, Oracle dan lain-lain.
\end{abstract}




\section{A. PENDAHULUAN}

Delphi adalah sebuah bahasa pemrograman dan lingkungan pengembangan perangkat lunak. Kata Delphi sendiri berasal dari bahasa Yunani yang berarti kuil yang dibangun untuk menyembah Dewa Apollo, salah satu Dewa yang disegani oleh orang-orang Yunani selain Dewa-Dewa lain seperti Jupiter, Titan dan lain sebagainya. Delphi awalnya sebuah proyek penelitian rahasia di Borland yang berevolusi menjadi sebuah produk yang disebut AppBuilder. Borland sebagai pengembang perangkat lunak yang sudah ada sejak era 1980an menggunakan ikon dan nama Delphi sebagai salah satu perangkat lunak pembantu pemrograman untuk membuat program yang sudah mengarah ke Pemrograman yang berorientasi pada objek atau dikenal dengan istilah OOP (Object Oriented Programming).

Pemrograman Delphi juga tidak bisa dipisahkan dari bahasa Turbo pascal yang diluncurkan pada tahun 1983 oleh Borland International Incorporation. Turbo pascal memang dirancang untuk dijalankan pada operasi DOS (Disk Operating System) yang merupakan sistem operasi yang banyak digunakan pada saat ini. 


\section{B. PEMBAHASAN/STUDI KASUS}

\section{Sejarah Borland Delphi 7.0}

Pada tahun 1992 muncul bahasa pemrograman baru bernama Borland Pascal 7 yang merupakan penggabungan dari Turbo Pascal dan Turbo pascal for windows.

Namun ternyata bahasa pemrograman baru tersebut ternyata masih sulit di gunakan. Trend penggunaan bahasa pemrograman visual untuk membangun sebuah aplikasi telah mendorong Borland membuat bahasa pemrograman baru pada tahun 1995 diperkenalkan kepengguna komputer sebuah bahasa pemrograman visual yang berbasis bahasa pascal. Bahasa pemrograman baru tersebut diberi nama Borland Delphi setahun kemudian versi ke dua dari delphi dilempar kepasaran.

Penggunaan delphi dapat mempersingkat waktu pemrograman, karena anda tidak perlu lagi menuliskan kode program yang rumit dan panjang untuk menggambar, meletakkan dan mengatur komponen. Selain itu anda dapat menyusun aplikasi yang lebih interaktif. Delphi menyediakan cukup banyak pilihan komponen interface aplikasi, antara lain berupa tombol menu, drop down, ataupun menu pop up, kotak text, radio button, check box, dan sebagainya.
Bahkan ada berbagai mascam komponen Skin tampilan yang beragam yang disediakan oleh beberapa vendor lainnya, seperti, SUIPack, Sxskincomponents, dan lain sebagainya. Anda tinggal memilih komponen yang dibutuhkan dengan klik mouse, mengatur tampilannya kemudian menuliskan sedikit kode program, maka aplikasi anda siap dijalankan.

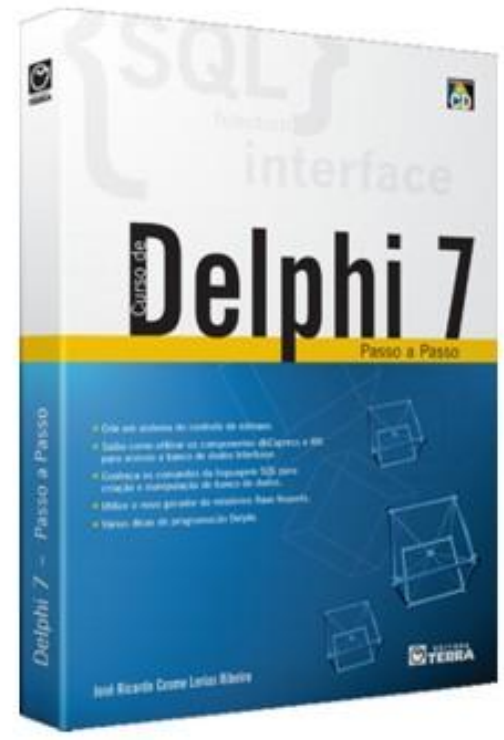

Delphi 7.0, versi terbaru yang dikeluarkan oleh Borland, memiliki support yang sangat tinggi terhadap data base-data base yang sudah terkenal (seperti MS Accsses, Paradox, Foxpro, Dbase, Oracce, dan lain sebagainya), dan dilengkapi dengan objek-objek yang baru sehingga memudahkan pembuatan database maupun program lainnya (Game, Utility dan lainnya). 


\section{Kelebihan Borland Delphi 7.0}

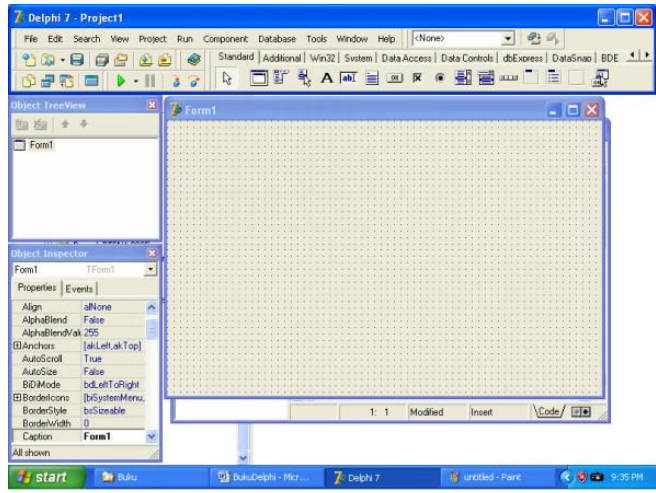

Borland delphi 7.0 merupakan pilihan bagi sebagian kalangan programmer untuk membuat aplikasi. Hal ini disebabkan kelebihan yang ada pada borland delphi 7.0 berikut ini beberapa kelebihan borlan delphi 7.0 antara lain :

\section{Berbasis Objek Orientid} programming, seperti bagian yang ada pada program dipandang sebagai suatu objek yang mempunyai sifat-sifat yang dapat diubah dan diatur, sehingga kita dapat membuat tampilan sebuah program dengan desain kita sendiri tanpa harus membuat codding yang panjang.

2. Suatu file EXE, setelah anda merancang program pada IDE Delphi akan mengkomplikasinya pada sebuah file executable tunggal. Program yang anda buat dapat langsung didistribusikan dan dijalankan pada komputer lain tanpa perlu menyertakan file lain, kecuali file yang beretensi *.exe atau Applikasi tersebut membutuhkan file lain seperti database, koneksi atau file pendukung lainnya, ini merupakan kelebihan yang sangat berarti.

3. Borland delphi 7.0 hadir bersama borland Kylix 3 yang berbasis Linux, bila ingin berganti flattform dari Windows ke Linux maka aplikasi yang dibuat di Delphi dapat dijalankan di Kylix 3 yang dikarenakan kedua produk tersebut merupakan produk Borland.

\section{Borland Delphi juga mempunyai beberapa versi, yaitu :}

1. Delphi 1 (1995)

Delphi, alat pengembangan pemrograman Windows Borland yang kuat pertama kali muncul pada tahun 1995. Delphi 1 memperluas bahasa Borland Pascal dengan menyediakan pendekatan berorientasi objek dan berbasis bentuk, kompiler kode asli yang sangat cepat, alat dua arah visual dan database yang hebat dukungan, integrasi erat dengan Windows dan teknologi komponen.

Berikut adalah Konsep Pertama Perpustakaan Komponen Visual

Delphi $1 *$ slogan: 
Delphi dan Delphi Client / Server adalah satu-satunya alat pengembangan yang memberikan manfaat Rapid Application Development (RAD) dari desain berbasis komponen visual, kekuatan dari compiler kode asli yang dioptimalkan, dan solusi klien / server yang dapat diskalakan.

\section{Delphi 2 (1996)}

Delphi 2 adalah satu-satunya alat Pengembangan Aplikasi Cepat yang menggabungkan kinerja kompiler kode asli 32-bit pengoptimalan tercepat di dunia, produktivitas desain berbasis komponen visual, dan fleksibilitas arsitektur basis data yang dapat diskalakan dalam lingkungan berorientasi objek yang kuat.

Delphi 2, selain dikembangkan untuk platform Win32 (dukungan dan integrasi penuh Windows 95), membawa grid database yang lebih baik, otomatisasi OLE dan dukungan tipe data varian, tipe data string panjang dan Warisan Bentuk Visual. Delphi 2: "Kemudahan VB dengan Kekuatan C ++"

\section{Delphi 3 (1997)}

Kumpulan alat pengembangan visual, performa tinggi, klien, dan server terlengkap untuk membuat perusahaan terdistribusi dan aplikasi berkemampuan Web.
Delphi 3 memperkenalkan fitur dan peningkatan baru di area berikut: teknologi wawasan kode, debugging DLL , template komponen, komponen DecisionCube dan TeeChart, teknologi WebBroker, ActiveForms, paket komponen, dan integrasi dengan COM melalui antarmuka.

\section{Delphi 4 (1998)}

Delphi 4 adalah seperangkat alat

Pengembangan profesional dan klien / server yang komprehensif untuk membangun solusi produktivitas tinggi untuk komputasi terdistribusi. Delphi menyediakan interoprerabilitas java, driver database berkinerja tinggi, pengembangan CORBA, dan dukungan Microsoft BackOffice, anda tidak pernah memiliki cara yang lebih produktif untuk menyesesuaikan, mengelola, memvisualisasikan, dan memperbarui data. Dengan Delphi, anda mengirimkan aplikasi yang kuat ke produksi, tepat waktu dan sesuai anggaran.

Delphi 4 memperkenalkan komponen docking, anchoring, dan constraining. Fitur - fitur baru termasuk AppBrowser, array dinamis, kelebihan metode, dukungan windows 98, dukungan OLE dan COM yang ditingkatkan serta dukungan database yang diperluas. 
5. Delphi 5 (1999)

Pengembangan produktivitas tinggi untuk Internet

Delphi 5 memperkenalkan banyak fitur dan peningkatan baru. Beberapa, di antara banyak lainnya, adalah: berbagai tata letak desktop, konsep bingkai, pengembangan paralel, kemampuan terjemahan , debugger terintegrasi yang ditingkatkan, kemampuan Internet baru ( XML ), lebih banyak kekuatan basis data ( dukungan ADO ), dll.

Kemudian, pada tahun 2000, Delphi 6 adalah alat pertama yang sepenuhnya mendukung Layanan Web baru dan yang muncul ...

Berikut ini adalah deskripsi singkat dari versi Delphi terbaru, bersama dengan daftar singkat fitur dan catatan.

\section{Delphi 6 (2000)}

Borland Delphi adalah lingkungan pengembangan aplikasi cepat pertama untuk Windows yang sepenuhnya mendukung Layanan Web baru dan yang sedang berkembang. Dengan Delphi, pengembang perusahaan atau individu dapat membuat aplikasi ebisnis generasi mendatang dengan cepat dan mudah.
Delphi 6 memperkenalkan fitur baru dan peningkatan di area berikut: IDE, Internet, XML, Compiler, COM / Active X, Dukungan database ...

Terlebih lagi, Delphi 6 menambahkan dukungan untuk pengembangan lintas platform ?? sehingga memungkinkan kode yang sama untuk dikompilasi dengan Delphi (di bawah Windows) dan Kylix (di Linux). Peningkatan lainnya termasuk: dukungan untuk Layanan Web, mesin DBExpress, komponen dan kelas baru ...

\section{Delphi 7 (2001)}

Borland Delphi 7 Studio menyediakan jalur migrasi ke Microsoft .NET yang telah ditunggu-tunggu oleh pengembang. Dengan Delphi, pilihan selalu menjadi milik Anda: Anda mengendalikan studio pengembangan e-bisnis lengkap dengan kebebasan untuk dengan mudah membawa solusi Anda lintas platform ke Linux.

\section{Delphi 8}

Untuk ulang tahun Delphi ke - 8 , Borland menyiapkan rilis Delphi yang paling signifikan: Delphi 8 terus menyediakan Visual Component Library (VCL) dan pengembangan Component Library untuk Crossplatform (CLX) untuk Win32 (dan Linux) serta fitur-fitur baru dan peningkatan kerangka kerja lanjutan, kompiler, IDE, dan waktu desain. 


\section{Kebutuhan Sistem}

Agar delphi versi 7.0 ini dapat dioperasikan dengan baik anda membutuhkan perangkat keras dan perangkat lunak dengan spesifikasi tertentu. Delphi memerlukan perangkat keras (Hardware) dengan ruang hard disk dan memori yang relatif besar untuk untuk pembuatannya tetapi untuk pemakaiannya / menggunakan hasil file Aplikasinya tidaklah membutuhkan spesifikasi yang besar, tergantung besar kecilnya program yang kita terapkan pada komputer tersebut, Spesifikasi minimal yang dibutuhkan antara lain :
1. Processor pentium $233 \mathrm{MHz}$ atau yang lebih tinggi.

2. Sistem operasi windows XP, windows 2000 atau windows 98.

3. Memori membutuhkan RAM 64 MB untuk edisi Architect, Enterprise, dan propesional, kecuali untuk personal $32 \mathrm{MB}$ disarankan $128 \mathrm{MB}$.

4. Untuk Hard disk minimal size yang kosong sebesar 500 Megabyte.

5. Mouse,Keybord.dll

\section{A. ID SECURITY}

QWTD44112377-ASP-524414475

\section{B. REFERENCE}

[1] O. M. Febriani and A. S. Putra, "Sistem Informasi Monitoring Inventori Barang Pada Balai Riset Standardisasi Industri Bandar Lampung," J. Inform., vol. 13, no. 1, pp. 90-98, 2014.

[2] A. S. Putra, "Paperplain: Execution Fundamental Create Application With Borland Delphi 7.0 University Of Mitra Indonesia," 2018.

[3] A. S. Putra, "2018 Artikel Struktur Data, Audit Dan Jaringan Komputer," 2018.

[4] A. S. Putra, "ALIAS MANAGER USED IN DATABASE DESKTOP STUDI CASE DB DEMOS."

[5] A. S. Putra, "COMPREHENSIVE SET OF PROFESSIONAL FOR DISTRIBUTE COMPUTING."

[6] A. S. Putra, "DATA ORIENTED RECOGNITION IN BORLAND DELPHI 7.0."

[7] A. S. Putra, "EMBARCADERO DELPHI XE 2 IN GPU-POWERED FIREMONKEY APPLICATION."

[8] A. S. Putra, "HAK ATAS KEKAYAAN INTELEKTUAL DALAM DUNIA TEKNOLOGY BERBASIS REVOLUSI INDUSTRI 4.0."

[9] A. S. Putra, "IMPLEMENTASI PERATURAN PERUNDANGAN UU. NO 31 TAHUN 2000 TENTANG DESAIN INDUSTRI BERBASIS 


\section{INFORMATION TECHNOLOGY."}

[10] A. S. Putra, "IMPLEMENTATION OF PARADOX DBASE."

[11] A. S. Putra, "IMPLEMENTATION OF TRADE SECRET CASE STUDY SAMSUNG MOBILE PHONE."

[12] A. S. Putra, "IMPLEMENTATION PATENT FOR APPLICATION WEB BASED CASE STUDI WWW. PUBLIKLAMPUNG. COM."

[13] A. S. Putra, "IMPLEMENTATION SYSTEM FIRST TO INVENT IN DIGITALLY INDUSTRY."

[14] A. S. Putra, "MANUAL REPORT \& INTEGRATED DEVELOPMENT ENVIRONMENT BORLAND DELPHI 7.0."

[15] A. S. Putra, "PATENT AS RELEVAN SUPPORT RESEARCH."

[16] A. S. Putra, "PATENT FOR RESEARCH STUDY CASE OF APPLE. Inc."

[17] A. S. Putra, "PATENT PROTECTION FOR APPLICATION INVENT."

[18] A. S. Putra, "QUICK REPORT IN PROPERTY PROGRAMMING."

[19] A. S. Putra, "REVIEW CIRCUIT LAYOUT COMPONENT REQUIREMENT ON ASUS NOTEBOOK."

[20] A. S. Putra, "REVIEW TRADEMARK PATENT FOR INDUSTRIAL TECHNOLOGY BASED 4.0."

[21] A. S. Putra, "TOOLBAR COMPONENT PALLETTE IN OBJECT ORIENTED PROGRAMMING."

[22] A. S. Putra, "WORKING DIRECTORY SET FOR PARADOX 7."

[23] A. S. Putra, "ZQUERY CONNECTION IMPLEMENTED PROGRAMMING STUDI CASE PT. BANK BCA Tbk."

[24] A. S. Putra, D. R. Aryanti, and I. Hartati, "Metode SAW (Simple Additive Weighting) sebagai Sistem Pendukung Keputusan Guru Berprestasi (Studi Kasus: SMK Global Surya)," in Prosiding Seminar Nasional Darmajaya, 2018, vol. 1, no. 1, pp. 85-97.

[25] A. S. Putra and O. M. Febriani, "Knowledge Management Online Application in PDAM Lampung Province," in Prosiding International conference on Information Technology and Business (ICITB), 2018, pp. 181-187.

[26] A. S. Putra, O. M. Febriani, and B. Bachry, "Implementasi Genetic Fuzzy System Untuk Mengidentifikasi Hasil Curian Kendaraan Bermotor Di Polda Lampung," SIMADA (Jurnal Sist. Inf. dan Manaj. Basis Data), vol. 1, no. 1, pp. 21-30, 2018.

[27] A. S. Putra, H. Sukri, and K. Zuhri, "Sistem Monitoring Realtime Jaringan Irigasi Desa (JIDES) Dengan Konsep Jaringan Sensor Nirkabel," IJEIS (Indonesian J. Electron. Instrum. Syst., vol. 8, no. 2, pp. 221-232.

[28] D. P. Sari, O. M. Febriani, and A. S. Putra, "Perancangan Sistem Informasi SDM Berprestasi pada SD Global Surya," in Prosiding Seminar Nasional Darmajaya, 2018, vol. 1, no. 1, pp. 289-294. 